\title{
Deteksi Gen Resisten Insektisida Organofosfat pada Aedes aegypti di Banyuwangi, Jawa Timur Menggunakan Polymerase Chain Reaction
}

\author{
(DETECTION OF ORGANOPHOSPHATE INSECTICIDES RESISTANT GENES \\ IN AEDES AEGYPTI IN BANYUWANGI DISTRICT, EAST JAVA \\ USING POLYMERASE CHAIN REACTION)
}

\section{Aditya Yudhana ${ }^{1}$, Ratih Novita Praja ${ }^{2}$, Maya Nurwartanti Yunita ${ }^{3}$}

\author{
${ }^{1}$ Laboratorium Helmintologi, Departemen Parasitologi Veteriner, \\ ${ }^{2}$ Laboratorium Bakteriologi dan Mikologi, Departemen Mikrobiologi, \\ ${ }^{3}$ Laboratorium Patologi, Departemen Patologi Veteriner, \\ Fakultas Kedokteran Hewan, Universitas Airlangga \\ Kampus-C Unair Jln. Mulyorejo, Surabaya, Jawa Timur, Indonesia, 60115 \\ Telp. (031) 5993016, Fax (031) 5990315; Email: aditvet@gmail.com
}

\begin{abstract}
ABSTRAK
Kabupaten Banyuwangi masih tercatat sebagai daerah yang belum sepenuhnya bebas dari wabah demam berdarah dengue (DBD). Perubahan genom nyamuk Aedes aegypti sebagai vektor utama virus dengue diperkirakan menjadi penyebab sulitnya pengendalian penyakit DBD. Ekspresi gen Voltage Gated Sodium Channel (VGSC) dapat dijadikan indikasi penting sejauh mana perkembangan nyamuk Aedes aegypti resisten terhadap insektisida golongan tertentu. Tujuan penelitian ini adalah untuk mendeteksi gen penyandi VGSC pada nyamuk $A$. aegypti yang berkaitan dengan mekanisme resistensi terhadap insektisida golongan organofosfat menggunakan teknik Polymerase Chain Reaction (PCR). Hasil uji resistensi susceptibility test menunjukkan sampel nyamuk A. aegypti dari tiga kecamatan di Kabupaten Banyuwangi yaitu Kecamatan Tegaldlimo, Purwoharjo, dan Banyuwangi resisten terhadap insektisida malathion $0,8 \%$ (kelompok organofosfat). Hasil deteksi gen melalui PCR didapatkan band yang muncul dengan panjang $250 \mathrm{bp}$. Hal tersebut menunjukkan bahwa gen pembawa resistensi insektisida (VGSC) telah terdeteksi pada sampel yang diuji. Berdasarkan hasil penelitian, disarankan untuk pengendalian vektor DBD di Kabupaten Banyuwangi dengan menggunakan alternatif insektisida selain dari golongan organofosfat.
\end{abstract}

Kata-kata kunci: resistensi; Aedes aegypti; Voltage Gated Sodium Channel (VGSC); Polymerase Chain Reaction (PCR)

\begin{abstract}
Banyuwangi is still listed as areas not completely free from hemorrhagic dengue fever outbreak. Changes in the genome of Aedes aegypti mosquito as the main vector of dengue virus is estimated to be the cause of difficulty in controlling the disease. Expression of Voltage Gated Sodium Channel (VGSC) genes can be used as an important indication of Aedes aegypti mosquitoes resistancy to certain groups insecticides. The purpose of this study was to detect the Voltage Gated Sodium Channel (VGSC) genes coding in Aedes aegypti using Polymerase Chain Reaction (PCR); as it is related to the mechanism of resistance to organophosphate insecticides groups. Results of resistency by susceptibility test showed that Aedes aegypti mosquito samples from three district ie. Tegaldlimo, Purwoharjo, and Banyuwangi were resistant to malathion $0.8 \%$ insecticide (organophosphates group). PCR results detected gen band with 250 bp length, which confirmed that insecticide resistance gene has been detected in the tested samples. Based on this study results, it is recommended to use alternative insecticides apart from organophosphate group for dengue vector control in Banyuwangi. .
\end{abstract}

Key words: resistence; Aedes aegypti; Voltage Gated Sodium Channel (VGSC); Polymerase Chain Reaction (PCR). 


\section{PENDAHULUAN}

Demam Berdarah Dengue (DBD) atau Dengue Hemorrhagic Fever (DHF) menjadi penyakit yang pola kejadiannya sulit dikendalikan. Wabah sporadis DBD tercatat dengan angka morbiditas $83 \%$ dan mortalitas mencapai $11 \%$ sehingga penyakit ini ditetapkan sebagai kejadian luar biasa. Manifestasi yang ditimbulkan oleh penyakit DBD berupa gejala sedang hingga berat bahkan menyebabkan kematian (WHO, 2014).

Penyakit DBD disebabkan oleh agen infeksi virus dengue yang terdiri dari berbagai serotipe DENV-1, -2, -3, dan -4. Virus dengue menginfeksi inang melalui vektor nyamuk Aedes aegypti yang juga merupakan vektor penyakit virus demam kuning (yellow fever) dan chikunguya. Infeksi virus dengue dapat berlangsung sangat cepat dan memungkinkan lebih dari satu serotipe agen infeksi. Masa inkubasi yang sangat singkat dan angka penularan yang tinggi dapat meningkatkan risiko pendaurulangan virus apabila nyamuk lain menghisap darah penderita sehingga menjadi vektor baru (Prasetyowati, 2012).

Berbagai macam upaya telah dilakukan untuk mencegah dan menanggulangi wabah DBD. Partisipasi aktif masyarakat untuk mengendalikan wabah DBD berupa perbaikan dan modifikasi kebersihan lingkungan, pengendalian fisik dengan raket elektrik dan insect net, pengendalian biologi berupa budidaya ikan pemakan jentik nyamuk, serta pengendalian kimiawi berupa fogging dan insektisida. Upaya pengendalian dengan metode abatisasi, penyuluhan, dan surveilance telah dilakukan secara berkala namun kejadian DBD masih terulang (Komalamisra, 2011).

Nyamuk $A$. aegypti dilaporkan telah mengalami resistensi terhadap insektisida cypermethrin $0,05 \%$ di beberapa wilayah di Jawa Tengah yaitu di Jepara, Blora, Kota Semarang, Kota Salatiga, Kota Surakarta, Kota Tegal, Kota Magelang, dan Kota Purwokerto (Widiarti, 2011). Hasil tersebut juga didukung dengan penelitian selanjutnya yang dilakukan di daerah Semarang oleh Sayono (2012) dan menyatakan bahwa resistensi insektisida cypermethrin yang terjadi pada $A$. aegypti ini juga berpengaruh terhadap status resistensi nyamuk Culex quinquefasciatus karena jumlahnya yang banyak dan terdapat pada target gen yang sama. Hasil penelitian terbaru pada tahun 2015 juga menunjukkan bahwa vektor DBD, A. aegypti di
Kota Semarang telah 100\% resisten terhadap insektisida golongan organofosfat yaitu malathion $0,8 \%$ dan permethrin $0,25 \%$.

Kabupaten Banyuwangi masih tercatat sebagai daerah yang belum sepenuhnya bebas dari wabah DBD. Laporan Dinas Kesehatan bahwa pada tahun 2014 telah terjadi 14\% kasus yang menderita DBD dari total presentase kejadian di Jawa Timur. Segala macam upaya telah dilakukan termasuk dengan melakukan pengendalian secara kimiawi dan abatisasi berkala sepanjang musim yang diperkirakan angka insidensi sangat tinggi sehingga dapat meredam wabah DBD (Dinkes Banyuwangi, 2015).

Perubahan genom nyamuk $A$. aegypti sebagai mayor vektor virus dengue diperkirakan menjadi penyebab sulitnya pengendalian penyakit DBD. Resistensi terhadap insektisida juga berpotensi masih tingginya siklus nyamuk vektor DBD tidak bisa ditanggulangi secara tuntas. Ekspresi gen spesifik dan autosom diindikasikan memengaruhi lokus pada genom terlebih lagi apabila timbul efek resistensi dari paparan insektisida. Voltage Gated Sodium Channel (VGSC) dapat dijadikan indikasi penting sejauh mana perkembangan nyamuk $A$. aegypti resisten terhadap insektisida golongan tertentu sehingga penggunaannya bisa dievaluasi dan diperbaiki untuk meningkatkan tindakan preventif (Sinkins, 2010). Tujuan penelitian ini adalah untuk mendeteksi gen penyandi VGSC pada nyamuk $A$. aegypti yang berkaitan dengan mekanisme resistensi terhadap insektisida golongan organofosfat menggunakan teknik Polymerase Chain Reaction (PCR).

\section{METODE PENELITIAN}

Penelitian dilaksanakan pada bulan JuliNovember 2015. Penelitian bersifat kualitatif yang menggunakan kombinasi kajian epidemiologi dengan pendekatan cross sectional study. Penentuan tempat berdasarkan pada kriteria khusus sampling stratifikasi pada penelitian yang dapat merepresentasi sampel yang dibutuhkan sebagai data penelitian. Sampel penelitian diambil berdasarkan wilayah yang mengalami kasus penyakit demam berdarah tertinggi di Kabupaten Banyuwangi yaitu dari Kecamatan Banyuwangi, Tegaldlimo, dan Purwoharjo. Sampel diperoleh dengan menggunakan ovitrap yang telah dipasang 
secara acak pada wilayah tersebut. Sampel yang telah berhasil dikoleksi selanjutnya dipelihara untuk dilakukan uji kerentanan insektisida di Laboratorium Instrumen PDD Banyuwangi dan deteksi gen penyandi resistensi insektisida di Institute of Tropical Diseases (ITD), Universitas Airlangga, Surabaya.

Uji Resistensi vektor demam berdarah terhadap insektisida dilakukan dengan metode Standard WHO impregnated paper yang kemudian dilanjutkan dengan deteksi pada gen penyandi VGSC menggunakan teknik Semi nested PCR. Visualisasi hasil PCR gen penyandi VGSC dilakukan dengan menggunakan metode elektroforesis pada gel agarose $2 \%$.

Ovitrap dipasang secara acak pada tiga wilayah endemis demam berdarah di Kabupaten Banyuwangi yaitu Kecamatan Tegaldlimo, Purwoharjo, dan Banyuwangi. Ovitrap diamati setiap hari. Koleksi sampel dari ovitrap dilakukan satu minggu kemudian dan didapatkan sampel berupa larva instar-1. Larva nyamuk yang berhasil dikoleksi selanjutnya dilakukan identifikasi dan dipelihara sampai menjadi nyamuk dewasa di laboratorium. Setiap hari larva diberi pakan serbuk campuran bekatul dan daging dengan perbandingan 10:4 sebanyak 75-200 mg, disesuaikan besarnya instar larva. Setelah larva menjadi nyamuk dewasa, selanjutnya dilakukan uji resistensi menurut standar WHO, menggunakan impregnated papers atau uji secara konvensional. Kondisi nyamuk dewasa yang digunakan untuk uji susceptibility adalah hasil dari pemeliharaan larva pertama (F1) dan berumur sekitar 2-3 hari.

Uji kerentanan insektisida standar WHO dilakukan dengan mempersiapkan 4-5 tabung dan pada setiap tabung uji dipasang kertas berinsektisida secara melingkar. Nyamuk sebanyak 20-25 ekor dimasukan ke dalam tabung uji. Nyamuk dikontakan dengan insektisida selama satu jam. Sebagai kontrol digunakan dua tabung yang diberi tanda dan dilengkapi kertas tanpa insektisida. Nyamuk diuji kontak dengan kertas berinsektisida selama satu jam, kemudian dipindahkan ke dalam tabung holding (penyimpanan) yang diberi tanda dengan label. Kematian nyamuk diamati dan dihitung setelah 24 jam penyimpanan. Selama penyimpanan kelembapan dijaga dan pada tabung holding dilengkapi handuk basah. Kriteria kerentanan ditentukan menurut Herath (2012): (i) kematian sebesar $99-100 \%=($ peka $)$; (ii) $80-98 \%=($ diperlukan verifikasi/toleran); (iii) $<80 \%=$ (resisten).

Nyamuk dewasa sebanyak 5-10 ekor dimasukan dalam tabung microtube untuk dilakukan isolasi DNA dengan metode Chelex100 Ion-Exchanger. Satu ekor nyamuk dewasa dimasukan ke dalam tabung mikrosentrifuge 1,5 $\mathrm{mL}$ dan ditambahkan PBS sebanyak $50 \mu \mathrm{L}$ ke dalam tabung kemudian nyamuk dihancurkan secera mekanik dengan menggunakan Teflon pestle. Homogenat yang diperoleh ditambahkan $1 \mu \mathrm{L} 0,5 \%$ saponin dingin dan diaduk pelanpelan. Tabung kemudian diinkubasi pada refrigerator suhu $4{ }^{\ddot{\mathrm{E}} \%} \mathrm{C}$ selama 24 jam. Homogenat nyamuk selanjutnya disentrifus dengan kecepatan 3000 rpm selama lima menit, supernatan dibuang untuk menghilangkan saponin. Setelah supernatan dibuang ke dalam tabung ditambahkan 1 mL PBS dan disentrifugasi selama lima menit dengan kecepatan $3000 \mathrm{rpm}$. Setelah selesai disentrifus ditambahkan air steril sebanyak $150 \mu \mathrm{L}$ dan $20 \%$ suspensi chelex sebanyak $50 \mu \mathrm{L}$. Kemudian dipanaskan/didihkan hingga suhu mencapai di atas $90{ }^{\mathrm{Ë}} \mathrm{C}$ selama 10 menit. Selesai dipanaskan selama 10 menit, dan dilanjutkan dengan divortex beberapa detik. Untuk memisahkan chelex tabung dicentrifus selama 10 menit dengan kecepatan $12.000 \mathrm{rpm}$. Supernatan (cairan yang di atas) diambil dan dipisahkan dari pellet (endapan). Supernatan tersebut yang digunakan untuk melakukan PCR. Supernatan yang terbentuk dipindahkan ke dalam tabung $1,5 \mathrm{~mL}$ yang baru. Campuran (supernatan) dibagi ke dalam dua tabung, satu tabung langsung digunakan dan tabung yang lain disimpan (Wooden et al., 1993).

Polymerase chain reaction adalah suatu metode melipatgandakan (amplifikasi) secara eksponensial suatu sekuen nukleotida tertentu secara in vitro. Seminested PCR merupakan metode amplifikasi DNA target dengan dua kali running PCR. Running PCR pertama menggunakan satu pasang primer (forward dan reverse), sedangkan pada running PCR kedua salah satu primernya (forward atau reverse) adalah primer yang digunakan pada PCR pertama. Primer adalah suatu sekuen oligonukleotida pendek yang berfungsi mengawali sintesis rantai DNA dalam reaksi berantai polymerase. Sebelum dilakukan PCR, komponen-komponen pereaksi, yaitu 10x dapar PCR; MgCl2 50mM; dNTP 10 mM; primer $k d r$ F; Primer $k d r$ R, enzim DNA polimerase Taq; $\mathrm{ddH}_{2} \mathrm{O}$; dan sampel DNA dicampur terlebih dahulu dalam tabung mikrosentrifus 0,2 $\mathrm{ml}$. 
Setelah pembuatan campuran pereaksi PCR selesai, tabung dimasukan ke dalam mesin thermal cycler. Primer-primer yang digunakan adalah primer forward $\mathrm{AgF} \_\mathrm{kdr}$; primer reverse An_kdr_R2; dan primer reverse AgR_kdr. Sekuen primer yang digunakan dalam strategi amplifikasi gen VGSC pada nyamuk Anopheles menurut Kazanidou et al. (2009) adalah sebagai berikut:

AgF_kdr : 5'GACCATGATCTGCCAAGATGGAAT3' An_kdr_R2 : 5'GAGGATGAACCGAAATTGGACA 3' AgR_kdr : 5'GCAAGGCTAAGAAAAGGTTAAGCA3'

Data yang didapat dari setiap variabel dependen, diakumulasi dan dilihat sebagai data kualitatif ada tidaknya perubahan mutasi genom yang disebabkan oleh resistensi insektisida akan dipaparkan secara deskriptif.

\section{HASIL DAN PEMBAHASAN}

Hasil uji kerentanan pada Tabel 1 menunjukkan bahwa populasi nyamuk $A$. aegypti yang berasal dari tiga kecamatan di Banyuwangi yaitu Tegaldlimo, Purwoharjo, dan Banyuwangi telah resisten terhadap insektisida malathion $0,8 \%$ dengan presentase kematian nyamuk sebesar $0 \%$ pada Kecamatan Tegaldlimo dan Purwoharjo (resisten 100\%) serta $1 \%$ pada kecamatan Banyuwangi (resisten 99\%).

Tabel 1. Jumlah dan persentase (\%) nyamuk Aedes aegypti yang mati pada uji kerentanan terhadap insektisida malathion $0,8 \%$.

\begin{tabular}{lcc}
\hline $\begin{array}{l}\text { Lokasi } \\
\text { Nyamuk } \\
\text { (kecamatan) }\end{array}$ & $\begin{array}{r}\text { Jumlah } \\
\text { nyamuk } \\
\text { uji *) }\end{array}$ & $\begin{array}{c}\text { Jumlah } \\
\text { mati } \\
(\%)\end{array}$ \\
\hline Tegaldlimo & 100 & $0(0)$ \\
Purwoharjo & 100 & $0(0)$ \\
Banyuwangi & 100 & $1(1)$ \\
Kontrol & 100 & $0(0)$ \\
\hline
\end{tabular}

Keterangan: *) Empat kali ulangan, masing-masing 25 ekor nyamuk; **) Kontrol (-) menggunakan nyamuk sampel menggunakan kertas tanpa insektisida

Hasil uji resistensi beberapa sampel nyamuk menggunakan metode standart WHO menghasilkan $A$. aegypti dari tiga kecamatan di Kabupaten Banyuwangi yaitu Tegaldlimo, Purwoharjo, dan Banyuwangi resisten terhadap insektisida malathion $0,8 \%$ (kelompok organofosfat). Isolasi DNA nyamuk menggunakan metode Chelex-100, diperoleh DNA dari nyamuk cukup banyak. Fragmen gen penyandi VGSC diidentifikasi menggunakan metode Semi-Nested PCR. Berdasarkan hasil amplifikasi fragmen target gen VGSC yaitu sepanjang 250 base pairs (bp) pada tiga sampel nyamuk yang diuji (Gambar 1).

Pada Gambar 1 ditunjukan hasil uji resistensi menggunakan teknik Semi-Nested PCR di tiga kecamatan. Kecamatan Tegaldlimo ditandai angka 1, Purwoharjo ditandai angka 2, Banyuwangi ditandai angka 3, dan 4 adalah marker. Hasil dari Kecamatan Tegaldlimo dan Purwoharjo terdeteksi band dengan angka 250 bp (basepair), sedangkan pada Kecamatan Banyuwangi terdeteksi band dengan angka 260 bp.

Uji coba resistensi pada sampel nyamuk menggunakan standar WHO, susceptibility test impregnated paper sangat membantu dalam mendapatkan bukti adanya mutasi gen VGSC yang berperan pada mekanisme resistensi. Hasil susceptibility test tersebut dapat digunakan sebagai indikator terjadinya resistensi insektisida karena memberikan gambaran sangat spesifik pada kejadian resistensi secara fenotip dan didukung dengan adanya band yang terlihat pada elektroforesis PCR gen penyandi VGSC nyamuk $A$. aegypti. Hasil yang didapat menunjukkan $A$. aegypti dari Kabupaten

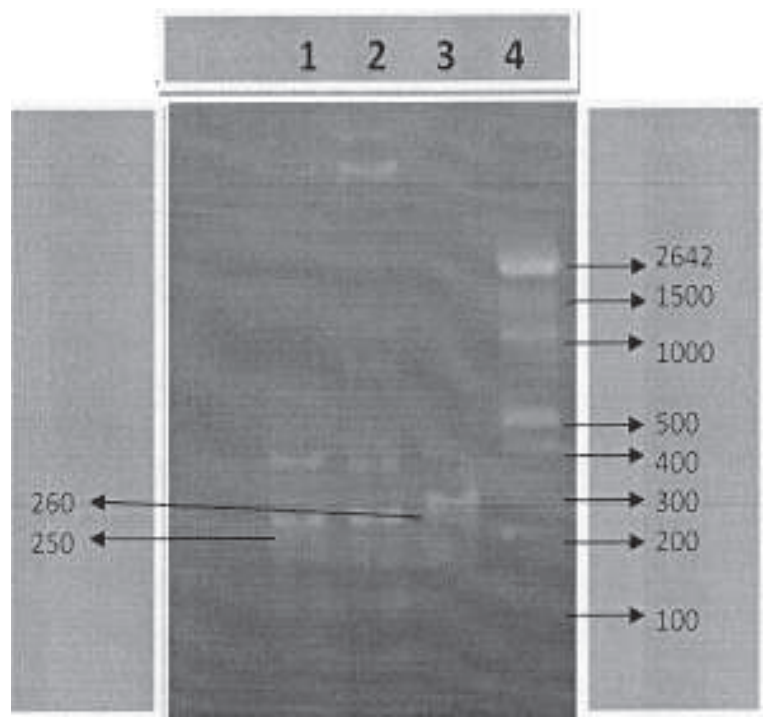

Gambar 1. Hasil deteksi gen VGSC menggunakan metode Semi-Nested PCR. 
Banyuwangi resisten terhadap insektisida malathion $0,8 \%$ (golongan organofosfat).

Hasil penelitian tersebut berkaitan dengan spesies A. aegypti yang telah mengalami penekanan secara selektif terhadap insektisida dari golongan organofosfat. Diketahui bahwa insektisida golongan organofosfat telah banyak digunakan masyarakat atau rumah tangga sehingga nyamuk $A$. aegypti sering terpapar dengan insektisida tersebut dan ditambah dengan insektisida dari golongan lain. Dinas Kesehatan Kabupaten Banyuwangi menginformasikan bahwa insektisida malathion telah digunakan di beberapa kecamatan di Banyuwangi untuk pengendalian $A$. aegypti secara fogging. Berdasarkan hasil susceptibility test nyamuk $A$. aegypi dari Kabupaten Banyuwangi juga sudah resisten terhadap insektisida malathion. dengan demikian kemungkinan mekanisme resistensi lain dapat berlangsung pada spesies nyamuk tersebut. Mekanisme resistensi yang dapat terjadi akibat insektisida golongan organofosfat adalah metabolik resisten, yaitu adanya enzim-enzim yang dapat mendegradasi insektisida sebelum mencapai sasaran atau target site (Brogdon, 1998). Contoh nyamuk yang digunakan dalam penelitian, semuanya resisten terhadap malathion (golongan organofosfat), kemungkinan tidak ditemukannya type $\mathrm{kdr}$-e. Type kdr-e adalah type mutasi kedua yang menghasilkan perubahan asam amino leucine menjadi serine (TTA menjadi TCA) (Soderlund, 2008; Kazanidou et al., 2009).

Berdasarkan penelitian yang sudah dilakukan, kemungkinan adanya type kdr-e terjadi pada individu serangga yang telah mengalami cross resisten dari DDT ke organofosfat (Soderlund, 2008). Pada penelitian ini dapat diketahui indikasi adanya mutasi dari leusine menjadi phenilalanin pada gen penyandi VGSC nyamuk $A$, aegypti dari Kabupaten Banyuwangi yang telah resisten terhadap Malathion 0,8\%. Berdasarkan Ranson et al. (2000) perubahan leusin menjadi phenilalanin menggambarkan tingginya resistensi $A$. aegypti terhadap insektisida golongan organofosfat. Apabila mutasi pada gen penyandi VGSC terjadi perubahan dari leusin menjadi serine, berkaitan erat dengan resistensi terhadap insektisida kelompok organochlorin (DDT), perubahan tersebut bisa terjadi pada Anopheles gambiae dan Culex pipiens (Martinez et al., 1998). Dalam skala rumah tangga, vektor demam berdarah dan malaria telah dikendalikan dengan insektisida karbamat dengan cara pemberian kelambu berinsektisida. Faktanya, vektor demam berdarah dari tiga kecamatan di Kabupaten Banyuwangi yaitu Tegaldlimo, Purwoharjo, dan Banyuwangi, juga telah mengalami resistensi terhadap insektisida golongan organofosfat (malathion). Pengendalian dengan metode fogging menggunakan insektisida organofosfat yang sebagian besar mempunyai bahan aktif malathion telah terbukti menyebabkan terjadinya resistensi dengan didukung hasil uji secara molekuler. Bukti bahwa telah terdeteksi gen penyandi VGSC insektisida golongan organofosfat pada nyamuk $A$. aegypti dari tiga kecamatan di Kabupaten Banyuwangi yaitu Tegaldlimo, Purwoharjo, dan Banyuwangi dapat memberikan manfaat bahwa program pengendalian vektor DBD A. aegypti seharusnya menggunakan insektisida yang tepat yaitu golongan insektisida yang belum menimbulkan resistensi.

Penelitian ini juga telah membuktikan bahwa populasi nyamuk $A$. aegypti dari tiga Kecamatan di Kabupaten Banyuwangi yaitu Tegaldlimo, Purwoharjo, dan Banyuwangi telah resisten terhadap insektisida malathion dari golongan organofosfat, padahal beberapa insektisida rumah tangga juga berbahan aktif karbamat. Penting untuk dilakukan studi lanjut tentang mekanisme resistensi lain yaitu mutasi glisin menjadi serine pada codon posisi 119 gen AchE 1 yang bisa menyebabkan terjadinya resistensi terhadap insektisida kelompok organofosfat dan karbamat (Mylene et al., 2010).

Konsep resistensi menyatakan bahwa penggunaan insektisida sintetik yang dilakukan secara terus menerus dalam waktu lama, tidak membunuh $100 \%$ serangga yang terpapar insektisida, dan selalu ada serangga yang tetap hidup. Pada awalnya jumlahnya amat sedikit, tetapi dalam periode tertentu akan mengalami peningkatan populasi, karena terjadi proses memperbanyak diri sekaligus mewariskan kemampuan untuk resisten terhadap insektisida kepada keturunan selanjutnya (Uthai, 2011). Khusus di tiga kecamatan di Kabupaten Banyuwangi yaitu Tegaldlimo, Purwoharjo, dan Banyuwangi, penggunaan insektisida dari golongan organofosfat perlu diawasi secara ketat karena mulai menimbulkan status resisten. Hasil ini dapat menjadi bahan pertimbangan pemerintah dan penduduk di Kabupaten Banyuwangi, apabila tetap menggunakan 
malathion untuk mengendalikan nyamuk $A$. aegypti, mengingat status resisten.telah mencapai $100 \%$ berdasarkan hasil uji kerentanan insektisida. Salah satu upaya yang bisa dilakukan untuk mencegah terjadinya resistensi $A$. aegypti terhadap insektisida golongan organofosfat di tiga kecamatan di Kabupaten Banyuwangi adalah dengan menerapkan manajemen rotasi insektisida. Walaupun banyak peneliti yang menilai bahwa manajemen ini hanya sebatas memperlambat terjadinya resistensi, bukan mencegah terjadinya resistensi. Akan tetapi sebelum ditemukannya rekayasa genetik nyamuk yang tepat sasaran, manajemen rotasi insektisida merupakan langkah efektif yang dapat dilakukan. Hal ini dijelaskan lebih lanjut oleh Shetty et al. (2013) yang menyatakan bahwa pada nyamuk spesies $A$. aegypti yang memiliki tiga gen resisten terhadap insektisida malathion, karbamat, dan cypermethrin, tidak berkembang menjadi nyamuk resisten bila diterapkan manajemen rotasi insektisida secara tepat.

\section{SIMPULAN}

Nyamuk $A$. aegypti di tiga kecamatan di Kabupaten Banyuwangi mempunyai gen penyandi resistensi insektisida VGSC yang terdeteksi dengan menggunakan teknik PCR.

\section{SARAN}

Berdasarkan hasil penelitian, disarankan untuk pengendalian vektor DBD di Kabupaten Banyuwangi dengan menggunakan alternatif insektisida selain dari golongan organofosfat.

\section{UCAPAN TERIMA KASIH}

Penulis mengucapkan terimakasih kepada semua pihak dan lembaga yang terlibat dalam penelitian deteksi resistensi insektisida di wilayah Kabupaten Banyuwangi, tim peneliti, dan keluarga yang selalu mendukung sehingga penelitian ini dapat terlaksana dengan baik.

\section{DAFTAR PUSTAKA}

Brogdon WG, Janet McAllister C. 1998. Insecticide Resistance and Vector Control. Journal of Emerging Infectious Diseases 4(4):605-613.

Dinas Kesehatan Banyuwangi. 2015. Profil Kesehatan Kabupaten Banyuwangi. Banyuwangi. Dikes Banyuwangi.

Herath PRJ. 2012. Insecticide Resistance Status in Disease Vectors and its Practical Implications. Intercountray Workshop on Insecticide Resistance of Mosquito. Proceeding National Acad Science USA 109(47):63-70.

Kazanidou A, D. Nikou, M. Gregoriou, J. Vontas, and G. Skavdis. 2009. A multiplex PCR assay for simulaneous genoyping of $\mathrm{kdr}$ and ace-1 Loci in Anopheles gambiae. American Journal Tropical Medicine Hygiene 80(2): 236-238.

Komalamisra N, Srisawat R, Phanbhuwong T, Oatwaree S. 2011. Insecticide susceptibility of the dengue vector, Aedes aegypti (L.) in Metropolitan Bangkok, Southeast Asian. $J$ Trop Med Public Health 42(4): 814-823.

Martinez-Torres D, Chandre F, Williamson MS, Darriet F, Berge JB, Devonshire AL, Guillet P, Pasteur N, Pauron D. 1998. Molecular characterization of pyrethroid knockdown resistance (kdr) in the major malaria vector Anopheles gambiae s.s. J Insect Mol Biol 7: $179-184$.

Mylene W, Berthomieu A, Berticat C, Lutfalla G, Negre V, Pasteur N, Philips A, Leonetti JP, Fort P, Raymond M. 2010. Insecticide Resistantce: a Silent Base Prediction. Biology Journal 14(14): 552-553.

Prasetyowati H, Rohmansyah, Nusa R. 2012 Peta upaya pencegahan DBD Kota Sukabumi tahun 2012. Jurnal Ekologi Kesehatan 11(4): 333-341.

Ranson H, Jensen B, Vulule JM, Wang X, Hemingway J, Collins FH. 2000. Identification of a point mutation in the voltage gated sodium channel gene of Kenyan Anopheles gambiae associated with resisance to DDT and pyrehroids. Insect Molecular Biology 9(5): 491-497. 
Sayono, Syafruddin D, Sumanto D. 2012. Distribusi Resistensi Nyamuk Aedes aegypti Terhadap Insektisida Sipermetrin di Semarang. Jurnal Ekologi Kesehatan 3(2): 73-82.

Shetty V, Sanil D, Shetty NJ. 2013. Insecticide susceptibility status in three medically important spesies of mosquitoes, Anopheles stephensi, Aedes aegypti and Culex quinquefasciatus, from Bruhat Bengaluruu Mahanagara Palike, Karnataka, India. Pest Manag Sci 69:257-267.

Sinkins S. 2010. Genome sequence of Aedes aegypti, a major arbovirus vector. $J S c i$ 3(16): 1718-1723.

Soderlund DM. 2008. Pyrethroid, knockdown resistance and sodium channels. Pest Manag Sci 64: 610-616.

Uthai UL, Rattanapreechachai P, Chowanadisai L. 2011. Bioassay and Effective
Concentration of Temephos Against Aedes aegypti Larvae and the Adverse Effect Upon Indigenous Predators :Toxorhynchites splendens and Micronecta sp. Asia Journal of Public Health 2(2): 67-77.

Widiarti, Heriyanti B, Boewono Dt. 2011. Peta Resistrensi Vektor Demam Berdarah Dengue Aedes aegypti Terhadap Insektisida Kelompok Organofosfat, Karbamat, dan Pyretroid di Provinsi Jawa Tengah dan Daerah Istimewa Yogyakarta. Jurnal Ekologi Kesehatan 3(2): 93-111.

Wooden J, Kyes S, Sibley CH. 1993. PCR and strain identification in Plasmodium falciparum. Parasitology Journal 9: 303305.

World Health Organization (WHO). 2014. Dengue Hemorrhagic Fever by Mosquito as Mayor Vector. Geneva, Switzerland. World Health Organization 130. 